Portland State University

PDXScholar

$10-2017$

\title{
Critical Library Management: Administrating for Equity
}

Candise Branum

Oregon College of Oriental Medicine

Turner Masland

Portland State University, masland@pdx.edu

Follow this and additional works at: https://pdxscholar.library.pdx.edu/ulib_fac

Part of the Library and Information Science Commons

Let us know how access to this document benefits you.

\section{Citation Details}

Branum, C., \& Masland, T. (2017). Critical Library Management: Administrating for Equity. OLA Quarterly, 23(2), 28-36.

This Article is brought to you for free and open access. It has been accepted for inclusion in Library Faculty Publications and Presentations by an authorized administrator of PDXScholar. Please contact us if we can make this document more accessible: pdxscholar@pdx.edu. 


\section{Critical Library Management: Administrating for Equity}

\author{
by Candise Branum \\ Director of Library Services, \\ Oregon College \\ of Oriental Medicine \\ cbranum@ocom.edu \\ and
}

\section{J. Turner Masland}

Access Services

Assistance Manager,

Portland State University

turner.masland@gmail.com

https://twitter.com/deweysnotdead



Candise is the Director of Library

Services at the Oregon College of

Oriental Medicine. She earned her

BS in Sociology from Portland State

University in 2005 and her MLS

from Emporia State University in

2009. In addition to managing

a small academic library, she is a

member of the OCOM Faculty

and teaches information literacy to

masters and doctoral students. She

is interested in radical pedagogy,

information ethics, using technology

to enhance UX, learning how to be

a better leader, and believes whole-

heartedly in both strategic planning and making things up as you go.

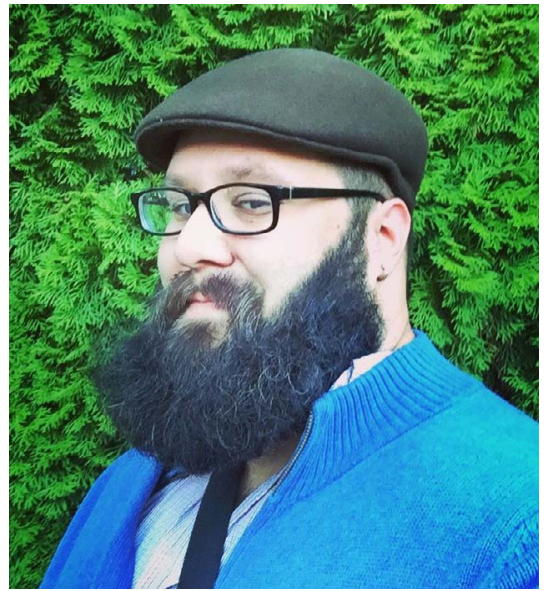

TURNER MASLAND

Turner Masland is the Assistant

Manager of Access Services at

Portland State University, where

he supervises the Resource Sharing

Unit and manages the department's student workers. He earned an MLS from Emporia State University in 2012 and a BA in Environmental Sociology from St. Lawrence University in 2006. Prior to his work at PSU, he has worked in a number of academic and medical libraries in the Portland area, giving him the privileged perspective entrenched in our region's dedicated and creative librarian community. He has just accepted the position of Access Services Manager at Sonoma State University, and will soon be moving to Northern California.

\section{Introduction}

Starting with the August 2016 NFL pre-season, Colin Kaepernick sat during the singing of the National Anthem. It was a simple act that carried great significance. He was refusing to pledge allegiance to a country that actively oppresses people of color. The protest continued into the regular football season, and it drew national attention. When first asked about the protest, he said: 
I am not going to stand up to show pride in a flag for a country that oppresses black people and people of color. To me, this is bigger than football and it would be selfish on my part to look the other way. There are bodies in the street and people getting paid leave and getting away with murder. (Wyche, 2016)

He soon moved to a bended knee, rather than sitting, to continue his protest while showing respect for members of the military who defend the country. Inspired by his action, other professional athletes followed his example. Some athletes also kneeled and some raised their fists. In one example, an entire team linked arms during the anthem. On September 4, 2016, professional soccer player Megan Rapinoe also took a knee during the anthem, later describing her decision as being:

... very intentional. It was a little nod to Kaepernick and everything that he's standing for right now. I think it's actually pretty disgusting the way he was treated and the way that a lot of the media has covered it and made it about something that it absolutely isn't. We need to have a more thoughtful, two-sided conversation about racial issues in this country. Being a gay American, I know what it means to look at the flag and not have it protect all of your liberties. It was something small that I could do and something that I plan to keep doing in the future and hopefully spark some meaningful conversation around it. It's important to have white people stand in support of people of color on this. We don't need to be the leading voice, of course, but standing in support of them is something that's really powerful. (Halloran, 2016)

Within a month of the protest starting, Kaepernick was on the cover of Time magazine. His defiance of the national anthem was immediately controversial and perceived as divisive. While Kaepernick's jersey quickly became the top selling jersey on the NFL's website, he was also voted the most disliked player in the league by NFL fans. On one side, Kaepernick is lauded as a hero fighting for social justice. On the other side, the protests are seen as unAmerican and disrespectful of police and military forces. Peter King, a Republican Congressman from Iowa, compared Kaepernick to the jihadist militant group ISIS. When confronted with uncomfortable conversations about oppression and privilege, it seems that his critics would rather look away and place blame on the protestor rather than what he is protesting.

The act at the heart of the protest was simple: Kaepernick placed his knee to the ground. But it was a tremendously brave act. He had millions of eyes on him, as NFL games remain one of the most popular televised events. He risked his job. Today he remains unsigned and there is speculation that he is being punished for his political beliefs. He saw injustice, and he took a stand. And library managers need to follow his example.

At its base, a library is a community organization. That community could be a neighborhood, a grade school, or a college campus. In order to best serve our communities, we must understand their needs, and both the positive and the negative influences on the community. The same macro-level issues that Kaepernick was protesting on a national level affect our libraries on the micro-level. We live in a country where minority communities face a multitude of overt and systemic forms of oppression: higher rates of incarceration, police harassment, job discrimination, and the environmental degradation of communities of color and individuals living in poverty; lack of state-enforced protection against job and housing discrimination based on sexual orientation and gender identities. Injustice is at 
the forefront of our current events as we see Black Lives Matter continue the fight for civil rights, the community of Flint, Michigan, go without clean drinking water, and Standing Rock fight for autonomy and protection against an unjust pipeline. When patrons walk into our libraries, this is the world they walk in from. Oppression in our communities is oppression against our library patrons. As library staff, we need to critically examine our professional practice. Does our work uphold systems of oppression? Do we offer respite? Do we offer a path towards liberation? Far too often, American libraries reinforce the legacy of oppression in America. We can find examples of this in our history (less than a generation ago, many libraries were segregated, with separate collections and buildings for white and black patrons) as well as how we organize library material (such as using outdated, problematic subject headings).

Every day, librarians have a choice: they can uphold the status quo, or they can choose to occupy a place of discomfort and fight against the status quo. Colin Kaepernick chose to fight. His action was bold and it cost him his job. But he has contributed to a long standing conversation about oppression in America and he has brought that conversation back into mainstream media. Librarians have often held up the status quo, oftentimes unknowingly but also because we have been afraid to take a bold step and resist oppression. Kaepernick could have stood by his teammates, with his hand over his heart, and simply played ball. But he chose to resist. Library managers, like Kaepernick, have a high level of visibility. And we have the opportunity to set policy and influence organizational culture. By moving toward a more just management practice we will move toward more just libraries and hopefully will contribute to the creation of more just communities. This article will define critical theory and use it as a framework for how we can continue to push against the status quo and to move libraries in the direction of liberation and equality.

\section{Critical Theory in the Library}

Critical theory is a framework for understanding social structures and social phenomena by examining struggles between domination and liberation. It is a critical way of looking at the world through the lens of power: who has the power, who doesn't have power, and what are the consequences of this dynamic. Rather than being a singular theory, critical theory is composed of many theory structures. One of the early examples of critical theory is class theory, developed in the first half of the 20th century. Class theory examined who owned the means of production, who had to sell their labor power to obtain resources, and how did these power imbalances affect the development of society. Growing from class theory, postcolonial theory examined the human consequences of external control and economic exploitation of native people and their lands. Critical race theory is a theoretical framework in the social sciences and humanities that is focused on the application of critical theory, a critical examination of society and culture, to the intersection of race and power. Feminist theory aims to understand the nature of gender inequality; it examines women's and men's social roles, experience, interests, division of labor, and feminist politics. Queer theory emerged in the early 1990s out of the fields of queer studies and women's studies, debunking the long established and rigid roles of the different sexes, genders, and sexualities, promoting the notion that gender and sexualities exist on a spectrum, that gender identity and sexuality bear no inherent relation to each other and that value judgements based on orientations and identities are regressive and dangerous. Looking back at the different examples of critical theory frameworks, it appears that each one grows out of the theories that came before it. 
Each of these examples has at its core the concepts and practice of questioning the dominant power structure.

The incorporation of critical theory and the practice of questioning dominant power structures into librarianship is growing, from conversations on social media to recently published articles and even entire conferences. We can see different ways that librarians and library staff incorporate critical theory into their daily practice. Perhaps the most ubiquitous incorporation of critical theory into library practice is through library instruction. There is a growing movement among teaching librarians who use a critical theory lens to influence both what they teach and how they teach. By using critical theory to influence their teaching methods, they have the ability to reach more students and help those students think critically about the world they live in. Teaching librarians will take critical theory into consideration when designing lesson plans, ensuring that they are not contributing to an invisible barrier that is traditionally built by oppression. Another example of how library practitioners implement critical theory is through the organization and access of our information. In one recent example, librarians successfully petitioned the Library of Congress to change the subject heading of "Illegal alien" to "Noncitizen" (Peet, 2016). This act sends an important message that the library profession recognizes the fact that people cannot be illegal and hopefully makes the library a more welcoming place. A third example of critical theory applied to the library setting is the growing movement recognizing the importance of getting diverse books into children's collections. Oftentimes a child's first time interacting with a person who is different from them is through their reading material. Books allow all readers to see the world through another person's perspective, leading to an increased level of empathy. Diverse books are also safe ways to help children understand the various levels of inequality that exist in our society.

One area of librarianship where the practical application of critical theory is greatly needed is library management. The conversation about power structures has not been deeply incorporated into library management practice, in part because traditional management upholds traditional hierarchies. The earliest forms of management in Western industrial societies chiefly entailed controlling workers and driving profits. While there have been great improvements in working conditions over the past two centuries, more modern forms of management still uphold hegemonic cultural norms. If you do a Google image search for the word "management," the search results will overwhelmingly be comprised of white men in business suits (N.B. when doing a Google image search of librarian, while the results are almost entirely female, they photo are all of white people which reflects the overwhelming whiteness of our profession). Managers in the library are in a key role to affect the overall tone and direction of the organizations they serve. Managerial tasks include recruitment and hiring, conducting performance reviews, writing and implementing policies and leading strategic planning processes. By applying critical theory frameworks to these tasks, managers will help their organizations move away from traditional and structural forms of oppression.

\section{Critical Library Administration in Practice}

We have so many thoughts and hopes and fears about what it means to be a library manager in the United States in 2017, but mostly we have questions. Will we continue to have funding? Will national policies affect how we view hate speech and is there even such thing as a "safe space?" How will the Trump Administration's policies affect the educational system? How do we best support communities who have been ravaged by systemic poverty, ha- 
tred, violence, and natural disasters while continuing to maintain our own mental health? As managers burdened with all of these uncertainties, one piece of the puzzle that we can actively control is the creation of policies and frameworks that support our staff and patrons in doing social justice work. If we are serious about creating systemic change, managers must recognize our position of power in library organizations and make a commitment to making sure people have the tools and support required in working towards equity. Management is both about human interactions and systems of power (Branum, 2017), and we must be intentional in creating systems to ensure this work is prioritized and funded, and that our staff is supported.

\section{Diversity Projects and Policies}

At its core, "diversity" focuses on modifying, not dismantling, the white dominant paradigm; in particular, diversity allows dominant groups the privilege of not having to think about how they inherently own a space, while the differing experiences of "other" groups become a point of focus. Additionally, diversity itself does not solve the problems of institutional racism. As librarians working in an overwhelmingly white profession, confronting racism is not just about ensuring that our workplaces are racially and ethnically diverse. We are called on to begin the process of examining that Whiteness and dismantling the structures that are explicitly or implicitly preventing people from historically marginalized groups from having support structures and power, from having their voices heard and respected, and from having the opportunity to lead (Brook, Ellenwood, \& Lazzaro, 2015; Galvan, 2015).

Although our profession is built upon white values (Brook, Ellenwood, \& Lazzaro, 2015; Galvan, 2015; Honma, 2005), librarians have done an excellent job in promoting multicultural communities through displays and programming. From bilingual storytime to learning about a community's cultural heritage and oral traditions (LaTronica, 2014), this is something libraries have thrived at; although simple displays and programming are really the low-hanging fruit, there remains real value in seeing oneself reflected in the library community. Mathuews (2016, p. 10) notes that diversity is important, as it focuses on representation and visibility, but "... social justice takes this line of thinking beyond simple representation to a more complex view of systems. Social justice seeks to ensure that all people participate in and benefit equally from a system." Additionally, diversity projects are often viewed as a sidebar to our "real" work. The real fact is that inequity affects not only us as individuals, but also our patrons and communities, and our missions and policies should address this.

For library managers and administrators, this will require you to not only look back at your current policies and make (sometimes substantial) changes, but also to create new frameworks. Good intentions do not create change-we do. We create change through policy, metrics and assessment. We investigate how our policies or space might be upholding white, heteronormative cultural values, and then we create action plans to address those issues. Using formalized policies and assessment will also create a system of accountability; by tracking and assessing our progress, we can see what we've done, what is working, and what is not. Systemic models for change such as Jackson and Holvino's Multicultural organizational development model (Holvino, 2008) or other organizational frameworks for social justice are generally implemented institution-wide, but libraries can also create departmentspecific plans and use the strategic planning process to investigate and address specific needs. 
Mission statements frame our values as an organization, and explicitly stating a commitment to equity will frame social justice work as a central tenet of what we do. Depending on the size and level of bureaucracy at your institution, this may be a complicated process. The rewards can be high, though: the process of reviewing and changing mission statements not only helps us formalize our values, but can be empowering for all parties engaged in this work. It sets the tone and creates expectations around the work we do and what we expect of one another.

\section{Action Plan for Critical Library Policies:}

Creating policy can be a painstaking process when you are being reactionary or otherwise forced to make changes. But the process can be really empowering (and dare I say fun?) when we create policy on our own terms that supports our library's values.

- Review your mission statement. If it doesn't directly address equity and social justice, and if it doesn't use explicitly anti-racist language, then work on changing it.

- Complete a climate assessment study. This will help identify what issues are most important to your stakeholders, and pinpoint areas where you are deficient. For an example, see Portland Community College's campus climate assessment results.

- Assessing services. Though we don't frame it as such, UX is social justice work in action. We must ensure that our services can be utilized by those that are differently abled, but also investigate how our policies or space might be upholding normative values that can make people feel like they don't belong.

- Formalize social justice work by building it into strategic plans and creating diversity plans. Rather than devaluing diversity initiatives as side-projects, they become integrated into our everyday work. See $A R L$ 's SPEC Kit 319: Diversity Plans and Programs (MaxeyHarris \& Anaya, 2010) for concrete examples of formalized diversity initiatives that have been utilized at a number of institutions; the University of Montana also documented their process in creating a campus-wide diversity initiative (Edwards, 2015).

\section{VocAlizING SupPorT}

The shootings of black Americans by law enforcement officers is a national epidemic. It is affecting our society in ways that we cannot even comprehend right now, re-traumatizing people of color every time a new injustice is perpetuated. The number of ICE arrests of undocumented noncriminals has doubled under the Trump Administration (Sacchetti, 2017), which also continues to push for a partial travel ban that specifically targets predominantly Muslim countries. Most recently, Trump announced a ban on transgender people serving in the U.S. military and has decided to let Deferred Action for Childhood Arrivals (DACA) expire, leaving the fates of nearly 800,000 children of undocumented immigrants to Congress. People of color and members of the LGBTQ community have legitimate concerns for their physical safety, and rather than working to ameliorate those fears, national policies are exacerbating them.

After the election of Donald Trump and the rise of racialized incidents on college campuses, Kim Bohyun wrote:

Sometimes, saying isn't much. But right now, saying it aloud can mean everything. If you support those who belong to minority groups but don't say it out loud, how would they know it? Because right now, nothing is obvious other than there is a lot of hate and violence towards minorities (Bohyun, 2016).

As library managers, this means that we have to be deliberate and explicit when it comes to making our support of targeted groups known. It requires not only the condemnation of white supremacy, sexism, and homophobia, but also vocalizing our commitment to creating and maintaining safer spaces. Many academic library directors have made public state- 
ments; the public statement posted by 86 members of the University of Oregon's staff and faculty is an excellent example:

In this time of increasing polarization of worldviews and escalating acts of aggression against members of marginalized groups, we the undersigned staff, faculty, and administrators in the UO Libraries wish to express our solidarity with students, faculty, and staff who advocate for the protection of human rights. We stand with those who oppose bigotry, racism, sexism, xenophobia, homophobia, ableism, and sexual predation and assault. We affirm that social injustices and oppression of people are wrong, and are a danger to the open, respectful environments we need to carry out our university and library missions (Open Letter to the UO Community, 2016).

In vocalizing our support for equitable systems, one critical point that we can't ignore is that the very nature of systemic racism makes this work easier for white people, while there are very real risks for people of color. Colin Kaepernick's bending of the knee was a simple physical motion, but the act itself was extremely loaded; as a black man in America, this was an act of bravery and defiance, one that many would argue lost him his career. People of color are often seen as rabble-rousers if they question administration, their concerns dismissed as being overly sensitive and their behaviors viewed as aggressive. In a profession like librarianship, which we know to be overwhelmingly white, people of color often have limited space to speak up and push boundaries for fear of reprisal, while white librarians are given the benefit of the doubt about their motives.

Intentionally or not, libraries uphold power imbalances that exist in American society; sometimes this is blatant discrimination such as historically segregated libraries in the south, but most often this plays out as microaggressions. Kaepernick, an individual black man, was punished for kneeling. But when hundreds of NFL players, coaches and owners linked arms or kneeled together on September 24th, it was a powerful demonstration of solidarity. Those who chose to kneel were not punished for stepping out of line because the league stood together. There is something librarians can learn from these athletes-one person speaking out is an act of rebelliousness, but a community standing in support of that person is an insurrection.

\section{Listening, Owning Up to Our Mistakes, \& Learning}

In our efforts to assert ourselves as leaders, one skill that is sometimes neglected is the skill of shushing ourselves. In outlining seven truths about doing critical race work, April Hathcock (2016) states that not only are white librarians guaranteed to screw up, but that this means you will (deservedly) be the target of "anger/hurt/frustration/wrath of the people of color you've offended." We librarians are a fearful bunch-fearful of losing jobs, losing support, and for white librarians in particular, fearful of being called out for being racist if we mess up. When we experience criticism (especially if we feel our actions were coming from a good place), it hurts, and our initial instincts are often to defend ourselves. This is not productive; rather, we must listen to those we wronged, understand our mistakes, and work to make it right. Hathcock notes that this work is intersectional, and can be applied to other ally work; whether we are supporting and advocating for LGBTQ folk, rural communities, or for those who are differently abled, we are bound to make mistakes. The work of taking 
critique is difficult, but by listening, learning, and making changes, we will also experience joy and fulfillment in our journey to become better humans and allies.

\section{In Conclusion, Libraries Resist}

We are living through a political period when it is essential that critical theory and social justice frameworks are incorporated into library management practice. Donald Trump's presidency is proving to be overtly racist and oppressive. His chaotic administration is inspiring neo-Nazis and white supremacists to march openly in the street, calling for the creation of a nation based on the exclusion of non-white communities, and the "Make America Great Again" platform has obvious roots in racism, patriarchy, misogyny, and xenophobia. Libraries need to be a haven for our most vulnerable library patrons: folks from Muslim communities; immigrants and refugees; transgender, genderqueer, and queer individuals; and our homeless community members. These library patrons will not only experience overt discrimination via official policy from the Trump administration, but could also be the victims of violence by hate groups who are emboldened by the administration.

Library managers wield influence and small changes can have great consequences. While Kaepernick's act of bending the knee was deceptively simple, many of the critical library management procedures we recommended in this article are relatively simple. They may lead to uncomfortable conversations, but growth and change often come from discomfort. Let us use our privilege as library managers to ensure the promotion of justice, equity, and liberation.

\section{References}

Bohyun, K. (2016, November 12). Say It Out Loud - Diversity, Equity, and Inclusion. Retrieved November 16, 2016, from http://www.bohyunkim.net/blog/archives/3587

Branum, C. (2017). Critlib Management: Leading and Inspiring Through a Social Justice Framework. Librarians With Spines. Hinchas Press, Sacramento, CA.

Brook, F., Ellenwood, D., \& Lazzaro, A. E. (2015). In Pursuit of Antiracist Social Justice: Denaturalizing Whiteness in the Academic Library. Library Trends, 64(2), 246-284.

Retrieved January 26, 2017, from https://doi.org/10.1353/lib.2015.0048

Edwards, J. B. (2015). Diversity plans for academic libraries: an example from the University of Montana. Library Leadership \& Management, 29(2). Retrieved from https://journals.tdl.org/llm/index.php/llm/article/view/7110

Galvan, A. (2015). Soliciting performance, hiding bias: whiteness and librarianship. In the Library with the Lead Pipe. Retrieved from http://tinyurl.com/ycoe9fmf

Halloran, J. D. (2016, September 4). ASN article: Megan Rapinoe Kneels For Anthem at NWSL Match. Retrieved September 6, 2017, from http://tinyurl.com/jyjarn8 
Hathcock, A. (2015, October 7). White Librarianship in Blackface: Diversity Initiatives in LIS. In the Library with the Lead Pipe. Retrieved from

http://www.inthelibrarywiththeleadpipe.org/2015/lis-diversity/

Hathcock, A. (2016, April 13). You're Gonna Screw Up. Retrieved August 1, 2017, from https:/aprilhathcock.wordpress.com/2016/04/13/youre-gonna-screw-up/

Holvino, E. (2008). Developing multicultural organizations: A change model. Chaos Management, Ltd. Retrieved from http://chaosmanagement.com/images/stories/pdfs/MCODmodel.pdf

Honma, T. (2005). Trippin' Over the Color Line: The Invisibility of Race in Library and Information Studies. InterActions: UCLA Journal of Education and Information Studies, 1(2). Retrieved from http://escholarship.org/uc/item/4nj0w1mp

Kyra. (2014, December 10). How to Uphold White Supremacy by Focusing on Diversity and Inclusion. Retrieved January 26, 2017, from http://tinyurl.com/pftf6yb

LaTronica, S. (2014, April 30). Libraries Working To Bridge The Cultural Divide. Retrieved from http://www.huffingtonpost.com/starr-latronica/libraries-cultural-divide_b_5241903.html

Mathuews, K. (2016). Moving Beyond Diversity to Social Justice: A Call to Action for Academic Libraries. Progressive Librarian, (44), 6-27.

Maxey-Harris, C., \& Anaya, T. (2010). SPEC Kit 319: Diversity Plans and Programs. Retrieved from http://publications.arl.org/Diversity-Plans-and-Programs-SPEC-Kit-319/

Open Letter to the UO Community from the Undersigned Library Staff, Faculty, and Administrators. (2016, November 15). Retrieved from http://tinyurl.com/ya2nme8x

Sacchetti, M. (2017, April 16). ICE immigration arrests of noncriminals double under Trump. Washington Post. Retrieved from http://tinyurl.com/mh5jua8

Wyche, S. (2016, August 27). Colin Kaepernick Explains Why He Sat During National Anthem. Retrieved September 6, 2017, from http://tinyurl.com/hub2tf3 